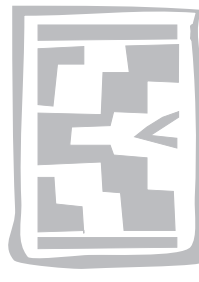

\title{
Poisonous plants
}

\author{
T.S. KELLERMAN
}

Section Pharmacology and Toxicology, Faculty of Veterinary Science, University of Pretoria Private Bag X04, Onderstepoort, 0110 South Africa

\begin{abstract}
KELLERMAN, T.S. 2009. Poisonous plants. Onderstepoort Journal of Veterinary Research, 76:19-23

South Africa is blessed with one of the richest floras in the world, which—not surprisingly-includes many poisonous plants. Theiler in the founding years believed that plants could be involved in the aetiologies of many of the then unexplained conditions of stock, such as gousiekte and geeldikkop. His subsequent investigations of plant poisonings largely laid the foundation for the future Sections of Toxicology at the Institute and the Faculty of Veterinary Science (UP). The history of research into plant poisonings over the last 100 years is briefly outlined. Some examples of sustained research on important plant poisonings, such as cardiac glycoside poisoning and gousiekte, are given to illustrate our approach to the subject and the progress that has been made. The collation and transfer of information and the impact of plant poisonings on the livestock industry is discussed and possible avenues of future research are investigated.
\end{abstract}

\section{INTRODUCTION}

At the time of the founding of Onderstepoort, Theiler, as the Director, either controlled or had a hand, in most of the research done at the Institute. He was a man of wide interests and included in these interests was botany. He rightly suspected that some of the then unexplained conditions of stock, such as geeldikkop and gousiekte, were in fact plant poisonings. His subsequent research on plant poisonings drew the attention of noted botanists such as $\mathrm{J}$. Burtt-Davy, I.B. Pole Evans and A.O.D. Mogg, initiating a fruitful collaboration between botanists and veterinarians that has persisted to this day. Theiler can thus be said to have laid the foundation for the future Sections of Toxicology at the Institute and Faculty (Gutsche 1979; Kellerman, personal observations 2008).

To the best of our knowledge, the unit now known as the Section of Toxicology came into being in about 1928 upon the appointment of D.G. (Douw)
Steyn as pharmacologist cum toxicologist at the Institute. He was succeeded by T.F. Adelaar (19481974), T.W. Naudé (1974-1976), T.S. Kellerman (1976-1998), J.P.J. Joubert (1998-2004) and finally Dharma Naicker (2004 to date), who is currently the Acting Head of the Section. Perhaps it is worthwhile to point out that over 90 years, from 1908 to 1998 , only five people had headed the Section. What is more, save for Theiler, all these incumbents actually knew each other, a state of affairs that held considerable benefits for the Section, as inter alia continuity of purpose was promoted and new appointees never lacked for mentors to guide them in their research.

\section{RESEARCH ON PLANT POISONINGS}

South Africa has one of the richest floras in the world, so it comes as no surprise that, included in this wide variety, are some 600 poisonous plants (Vahrmeyer 1981). Moreover, since many of these 
plants are unique to the region much of the research on poisonous plants done abroad had little application here. As a result, South African investigators could look only to themselves for answers to the problems caused by many of these plants.

In the 1990s, a study of the distribution, diagnosis and estimated economic impact of plant poisonings and mycotoxicoses in South Africa was carried out (Kellerman, Naudé \& Fourie 1996). The study revealed that the most important poisonings (poisonings by cardiac glycoside-containing plants, geeldikkop, vermeersiekte, gifblaar poisoning, diplodiosis and Lantana poisoning) were the same as those with which Theiler and the early workers long ago had battled. This finding was expected, as the first plant poisonings brought to their notice were the most damaging and, by inference, those for which farmers most urgently needed answers.

To review the history of research on poisonous plants at the Institute over the last hundred years in the limited space allowed would be an impossible task. In view of this, only the research on some of the major problems listed in the 1996 study will be briefly outlined, principally to illustrate our approach to the subject and the progress that has been made.

\section{Cardiac glycoside poisoning}

According to that study, poisoning with cardiac glycoside-containing (CG) plants, collectively, is the single most important plant poisoning in South Africa, annually accounting for about $33 \%$ of all cattle deaths from plant poisonings.

Two types of cardiac glycosides are contained by South African plants, namely cardenolides and bufadienolides. Cardenolides have a single unsaturated five-member lactone ring on $\mathrm{C} 17$ of the steroid molecule while bufadienolides have a doubly unsaturated six member (pentadienolide) lactone ring in that position (Naudé 1977). All the important cardiac glycoside-containing plants in South Africa have bufadienolides as their active principles (Kellerman, Coetzer, Naudé \& Botha 2005).

Poisoning by bufadienolides may be either acute or chronic, depending on whether the bufadienolides contained by them have a cumulative effect or not. Acute poisoning affects the respiratory, cardiovascular, gastrointestinal and nervous systems, usually leading either to death or recovery within days. Cumulative or krimpsiekte-causing bufadienolides on the other hand involve mainly the nervous system sometimes resulting in sudden death or more commonly, protracted paresis or paralysis. Affected animals typically assume a characteristic pose (with the feet together and back arched), lie down frequently and develop protracted paresis /paralysis. A few display persistent torticolis (Kellerman et al. 2005).

The first report of research on cardiac glycoside poisoning that we could trace was by Soga, who in 1891 succeeded in reproducing krimpsiekte by dosing a 'plakkie', Tylecodon ventricosis, to goats (Soga 1891). His finding was confirmed by Tomlinson \& Dixon cited by Henning (1926), who also incriminated Tylecodon wallichii in the aetiology of the disease. The next notable advance in krimpsiekte and plant-induced cardiac glycoside poisoning was the isolation by Naudé \& Potgieter (1966) of the toxic principle, a bufadienolide, from Moraea pallida, followed closely by yet another from $T$. wallichii by Van Rooyen \& Pieterse (1968).

Consequent to this pioneering work many plants, including several plakkies (Tylecodon, Cotyledon and Kalanchoe spp.), tulp (Moraea spp.), slangkop (Drimia spp.) and kruidjie-roer-my-nie (Melianthus spp.) have been shown similarly to contain bufadienolides (Kellerman et al. 2005).

Knowing the nature of the active principles was very important as this opened up the overseas literature on extensively researched cardiac glycosides such as digitalis. Information on the mode of action was particularly helpful, since amongst others, it had bearing on treatment.

Attention could then be paid to the treatment and control of the poisoning. Several therapeutic agents were tested without notable success until Joubert \& Schultz (1982) showed that drenching poisoned animals with activated charcoal gave excellent results. This simple, practical and economical treatment has saved the lives of innumerable animals.

The current methods of controlling plant poisonings, namely by the mechanical or chemical eradication of plants, fencing off infested areas, grazing management, etc., all involve changing the environment in some way. However, changing the environment is not always feasible, particularly in communal or extensive commercial farming areas where capital is lacking, cash turnover from livestock production is slow and labour is scarce. Since the environment could not easily be changed, means had to be found of manipulating the animals to resist or avoid poisoning.

Firstly, the feasibility of immunising stock against plant poisonings was investigated. Joubert accord- 
ingly attempted to prepare a vaccine against cardiac glycoside poisoning by conjugating cardiac glycosides with bovine serum albumin. Although sheep developed strong immunity to a particular cardiac glycoside in the vaccine, little cross-immunity could be demonstrated against challenges with non-homologous cardiac glycosides or cardiac glycosidecontaining plants (J.P.J. Joubert, unpublished data 1982). The issue of developing a vaccine against poisoning by cardiac glycoside-plants is currently being re-examined by C.J. Botha (personal communication 2007), with initial promising results.

South African stockmen traditionally know that animals that grow up on infested veld learn to avoid certain poisonous plants. This explains why poisoning by these plants (e.g. Moraea spp.) occur mostly in naïve stock, newly introduced from non-infested areas. A project was immediately launched to extract and characterise the factor(s) responsible for this conditioned feed aversion (CFA) in yellow tulp, Moraea pallida. According to Kellerman et al. (2005), 'sniffer sheep', previously averted to yellow tulp, were used to sense the presence of the aversive substance in fractions of the plant mixed in maize meal. Refusal of the fractions consumed by naïve control sheep indicated the presence of an aversive substance, provided the 'sniffer sheep' were still willing to eat pure maize meal. By following the refused fractions-obtained by solvent extraction and chromatographic separation-epoxyscillirosidin, the main toxic principle of yellow tulp, was identified as the 'aversive substance' (Snyman, Kellerman, Schultz, Joubert, Basson \& Labuschagne 2004). Field trials revealed that averted cattle had difficulty in recognizing epoxyscillirisodin in yellow tulp growing naturally on kikuyu pastures. To circumvent this problem, an epoxyscillirosidin-free hexane tulp extract, serving as an 'identification factor' for tulp, was dosed in conjunction with the aversion factor, during induction of aversion. Some evidence was also found that the epoxyscillirosidin used to induce aversion, could contribute to the poisoning of animals during the aversion process on tulp-infested pastures. Partially replacing the epoxyscillirosidin with lithium chloride, a non lethal aversive agent that does not affect the heart, successfully addressed the problem (Snyman et al. 2004; Snyman, Schultz, Joubert, Basson \& Labuschagne 2003). The investigation is continuing.

\section{Gousiekte}

The fifth most important plant poisoning in the 1996 study (Kellerman et al. 1996), gousiekte, is certainly the most unusual. It is typically characterized by ap- parently healthy ruminant animals suddenly dropping dead from heart failure some 6-8 weeks after ingesting certain members of the Rubiaceae (Gardenia) family.

Walker (1908), the Government Veterinary Officer at Ermelo, first reported the appearance of gousiekte, a serious new disease which caused the sudden death of sheep. He was convinced that the causative agent was a plant. There the matter rested until 1915, when more than 1000 sheep died of gousiekte after trekking across a 'toxic' farm near Kaalfontein in the vicinity of Pretoria. In a series of experiments conducted on the farm by Theiler and co-workers, they established beyond doubt that Pachystigma pygmaeum was responsible for the outbreak (Theiler, Du Toit \& Mitchell 1923). Subsequently, several other members of the Rubiaceae have been incriminated by various workers as the aetiology of gousiekte, namely Pachystigma thamnus, Pachystigma latifolium, Fadogia homblei, Pavetta harborii and Pavetta schumanniana(Kellerman et al. 2005).

Studies on the clinical signs and cardiodynamics of gousiekte (Pretorius \& Terblanche 1967; Pretorius, Terblanche, Van der Walt \& Van Ryssen 1973) and the subcellular effects on energy production and the contractile mechanism of the myocardium (Snyman, Van der Walt \& Pretorius 1982a, b) suggested that the primary lesion in gousiekte was inhibition of the contractile mechanism of the myocardium. In the 1990s, the matter was taken further by Fourie and co-workers, who launched an ambitious project to isolate the cardiotoxin and to explain the pathogenesis of the disease. Gousiekte is a particularly challenging disease to investigate, inter alia because initially only ruminants were known to be affected, large amounts of plant material of variable toxicity are required to induce the disease, and there is a latent period of approximately six weeks to contend with. In a most accomplished piece of research, a pure toxin was isolated from $P$. harborii (Fourie 1994; Fourie, Erasmus, Schultz \& Prozesky 1995) and identified by Vleggaar as a polyamine, pavetamine (R. Vleggaar, personal communication 1997). Polyamines are highly biologically active compounds affecting many functions in the body including cell growth. Studies in rats by Schultz and her co-workers confirmed that pavetamine in common with other polyamines inhibits the synthesis of proteins. Ongoing investigations by these workers indicate that pavetamine acts by inhibiting the synthesis of the contractile protein, myosin, in myocardial cells. When the depletion of myosin through natural degradation reaches a level where the contractility 
Poisonous plants

of the myocardium is compromised, sudden heart failure ensues.

\section{Prospects for future research}

Owing to the diligent efforts of veterinarians and other workers over the last hundred years, most of the plant poisonings affecting stock in South Africa have been identified and described. Amongst others, their botanical, toxicological and pathological aspects have been studied and in many the active principles have been isolated and characterized. Although new poisonings, such as the nephrotoxic condition of cattle in the Northern Cape Province caused by Nolletia gariepina (Du Plessis 2004), will still sporadically surface, the era of 'descriptive' toxicology is slowly coming to an end. One of the many new priorities would be in depth studies of the pathogenesis of our plant poisonings, preferably at subcellular level (see gousiekte), partly in the expectation that a better understanding of their modes of action might lead to the development of effective therapies. The question of therapy in general has been briefly discussed under the heading of cardiac glycoside poisoning.

The most immediate challenge facing researchers today is the control and prevention of plant poisonings in the field. According to the discussions under the heading of cardiac glycoside poisoning, it appeared that manipulating the animal to avoid or resist poisoning had a better chance of success than trying to change the environment.

The problems experienced in the development of vaccines against certain plant poisonings were touched on, but this aspect has not yet been fully exploited and should be further investigated.

The very promising research on CFA as a means of teaching stock to avoid plant poisoning has been fully discussed elsewhere in this publication. One of the chief attractions of CFA is that, being one of the nature's own ways of protecting stock, it is completely environmentally friendly. Averted animals are able to graze with impunity on infested pastures without the ecology of the system first having been disturbed by human intervention; for instance, by the use of herbicides or the mechanical eradication plants.

More fanciful perhaps, is the prospect of introducing genes involved in resistance to plant poisonings from the rumen flora of wild animals into that of cattle and sheep. Genetic manipulation of rumen flora could perhaps be considered as one of the avenues of future research on the control of plant poisonings in South Africa.

\section{Transmission of technology}

Steyn was one of the most dominant figures on the toxicological scene in South Africa during the first half of the previous century, having published prolifically in both scientific and popular journals. To him must also go the credit for writing the first reference book, The toxicology of plants in South Africa, thereby cementing his place in the annals of toxicology at Onderstepoort (Steyn 1934). A second volume, Vergiftiging van mens en dier, followed some 14 years later, but this was aimed mainly at the farming community (Steyn 1949).

By the early 1980 s a pressing need for a modern work arose as the one by Steyn, published more than 50 years before, was dated and long out of print. As a result, academics, veterinarians, students and researchers in related fields, amongst others, did not have a South African reference book to consult on plant poisonings. Plant poisonings and mycotoxicoses of livestock in southern Africa, written in conjunction with Coetzer (pathologist) and Naudé (toxicologist) duly appeared in 1988 (Kellerman, Coetzer \& Naudé 1988). Having a pathologist as a co-author was particularly useful as pathology plays a pivotal role in the diagnosis of many of our plant poisonings. In the 1990s the manuscript was updated to include information on developments in the field of plant poisoning since 1988. The need for a second edition was made more urgent by the fact that by the late 1990s all the senior researchers in toxicology, save for C.J. Botha at the Faculty, had either retired or were about to retire, leaving a serious vacuum in this field of expertise at Onderstepoort. This gave rise to a worrying lack of mentors to guide the next generation of young researchers responsible for taking toxicology into the future. It was hoped that the second edition, published in 2005 and in which Botha was co-opted as a co-author, would help fill this gap (Kellerman et al. 2005).

\section{CONCLUSION}

Looking back over the past century, Onderstepoort (both the Institute and Faculty), can be seen to have played a leading role in the investigation of the plant poisonings in southern Africa. This achievement would not have been possible, however, without the century-long dedication of many South African veterinarians from all over the country and our many 
collaborators in various disciplines from here and abroad.

\section{REFERENCES}

DU PLESSIS, E.C. 2004. Pathological investigation of the nephrotoxic effects of the shrub Nolletia gariepina DC Mattf. in cattle. M.Med.Vet (Path.) thesis, University of Pretoria.

FOURIE, N. 1994. Isolation of the cardiotoxin from gousiekte-inducing plants and investigation of the pathogenesis and diagnosis of the disease. Ph.D. thesis, University of Pretoria.

FOURIE, N., ERASMUS, G.L., SHULTZ, R.A. \& PROZESKY, L. 1995. Isolation of the toxin responsible for gousiekte, a plantinduced cardiomyopathy of ruminants in southern Africa. Onderstepoort Journal of Veterinary Research, 62:77-87.

GUTSCHE, T. 1979. There was a man: The life and times of Sir Arnold Theiler K.C.M.G. Cape Town: Howard Timmins.

HENNING, M.W. 1926. Krimpsiekte. Report on Veterinary Research, Union of South Africa, 12:331-365.

JOUBERT, J.P.J. \& SCHULTZ, R.A. 1982. The minimal effective dose of activated charcoal in the treatment of sheep poisoned with the cardiac glycoside containing plant Moraea polystachya (Thunb) Ker-Gawl. Journal of the South African Veterinary Association, 53:265-266.

KELLERMAN, T.S., COETZER, J.A.W. \& NAUDÉ, T.W. 1988. Plant poisonings and mycotoxicoses of livestock in southern Africa. Cape Town: Oxford University Press Southern Africa.

KELLERMAN, T.S., NAUDÉ, T.W. \& FOURIE, N. 1996. The distribution, diagnosis and estimated economic impact of plant poisonings and mycotoxicoses in South Africa. Onderstepoort Journal of Veterinary Research, 63:65-90.

KELLERMAN, T.S., COETZER, J.A.W., NAUDÉ, T.W. \& BOTHA, C.J. 2005. Plant poisonings and mycotoxicoses of livestock in Southern Africa, $2^{\text {nd }}$ ed. Cape Town: Oxford University Press Southern Africa.

NAUDÉ, T.W. \& POTGIETER, D.J.J. 1966. A preliminary note on the isolation and pharmacological actions of the toxic principles of Homeria glauca (W \& E). N.E. Br. Journal of the South African Veterinary Association, 37:73-75.

NAUDÉ, T.W. 1977. The occurrence and significance of South African cardiac glycosides. Journal of the South African Biological Society, 18:7-20.

PRETORIUS, P.J. \& TERBLANCHE, M. 1967. A preliminary study on the symptomatology and cardiodynamics of gousiekte in sheep and goats, Journal of the South African Veterinary Medical Association, 38:29-53.

PRETORIUS, P.J., TERBLANCHE, M., VAN DER WALT, J.D. \& VAN RYSSEN, J.C.J. 1973. Cardiac failure in ruminants caused by gousiekte, in Cardiodynamics, Vol. 2, edited by E. Bajusz, G. Rona, A.J. Brink \& A. Lochner. Baltimore: University Park Press.

SNYMAN, L.D., VAN DER WALT, J.J. \& PRETORIUS, P.J. 1982a. A study on the function of some subcellular systems of the sheep myocardium during gousiekte. 1. The energy production system. Onderstepoort Journal of Veterinary Research, 49:215-220.

SNYMAN, L.D., VAN DER WALT, J.J. \& PRETORIUS, P.J. 1982b. A study on the function of some subcellular systems of the sheep myocardium during gousiekte 2 . The contractile protein system. Onderstepoort Journal of Veterinary Research, 49:221-226.

SNYMAN, L.D., SHULTZ, R.A., JOUBERT, J.P.J., BASSON, K.M. \& LABUSCHAGNE, L. 2003. Conditioned feed aversion as a means to prevent tulp (Homeria pallida) poisoning in cattle. Onderstepoort Journal of Veterinary Research, 70:4348.

SNYMAN, L.D., KELLERMAN, T.S., SHULTZ, R.A., JOUBERT, J.P.J., BASSON, K.M. \& LABUSCHAGNE, L. 2004. Conditioned feed aversion (CFA) as a means of preventing the intake of yellow tulp (Homeria pallida) by livestock, in Poisonous plants and related toxins, edited by T. Acamovic, C.S Stewart \& T.W. Pennycott. Wallingford: CAB International: 531-539.

STEYN, D.G. 1934. The toxicology of plants in South Africa. Central News Agency.

STEYN, D.G. 1949. Vergiftiging van mens en dier. Pretoria: Van Schaik.

SOGA, J.F. 1891. Diseases 'Nenta' in goats. Agricultural Journal of the Cape of Good Hope, 3:40-142.

THEILER, A., DU TOIT, P.J. \& MITCHELL, D.T. 1923. Gousiekte in sheep. Report on Veterinary Research, Union of South Africa, 9 \& 10:9-105.

VAN ROOYEN, G.G. \& PIETERSE, M.J. 1968. Die chemie van Cotyledon walichii Harv. (kandelaarbos). 11. Die isolering van ' $\mathrm{n}$ bufadienolied. Journal of the South African Chemical Institute, 21:89-90.

VAHRMEYER, J. 1981. Poisonous plants of southern Africa that cause stock losses. Cape Town: Tafelberg Publishers.

WALKER, J. 1908. Gouw-Ziekte. A disease of sheep. Report of the Government Veterinary Bacteriologist of the Transvaal, 1908-1909: 74-99. 